\title{
ANALISIS KAPASITAS KOLAM RETENSI UNTUK PENGENDALIAN BANJIR DI DAS BUAH KOTA PALEMBANG
}

\author{
Febrinasti Alia' $^{1)}$, Sakura Yulia Iryani' ${ }^{2}$, Nuzula Ramadhanti ${ }^{3)}$ \\ 1, 2,3) Jurusan Teknik Sipil FT Universitas Sriwijaya, Jl. Raya Prabumulih - Km 32 Indralaya, Ogan Ilir, Sumatera Selatan
}

\begin{abstract}
According to Public Works Office of Palembang City, Buah Watershed is listed as one of priority areas that requires immediate flood management actions. Flat terrain, high rainfall intensity, tidal fluctuation worsens by massive land use change, are major causes that increase surface water runoff. Therefore, retention basins as one of technical solutions are expected to accommodate runoff discharge and reduce flood. This study aims to analyze the existing hydrological conditions of Buah watershed and to simulate the effectiveness of designed retention basins on peak flow reduction. Hydrological analysis using SCS Unit Hydrograph Model, HEC-HMS combine with spatial analysis using GIS in 26 subcatchment areas resulted on peak discharges range from $1,27 \mathrm{~m}^{3} / \mathrm{s}-15,71 \mathrm{~m}^{3} / \mathrm{s}$. Furthermore, there are 12 proposed retention basins within study area ranges from $0,580 \mathrm{Ha}-3,967 \mathrm{Ha}$ that are designed to reduce the peak discharge. Simulation result of flood discharge reduction using HEC-HMS indicates that the effectiveness of retention basins in proposed locations varies from $0,03 \%-80,05 \%$ depending on watershed areas, land availability, and the depth of retention basins.
\end{abstract}

Key Words: flood control, hydrologic modeling, retention basin, spatial analysis, watershed

\section{PENDAHULUAN}

Salah satu permasalahan serius yang melanda beberapa daerah perkotaan dan pedesaan di Indonesia adalah banjir. Banjir tersebut bukan murni karena faktor alam semata, melainkan akibat tidak terkendalinya perubahan pemanfaatan lahan tanpa mengindahan kelestarian daerah aliran sungai dari hulu hingga hilir. Menurut (Suripin, 2004) bagian yang harus diperhatikan dalam pengendalian banjir tidak hanya aliran permukaan, tetapi juga limpasan (runoff). Laju dan volume limpasan dipengaruhi oleh distribusi dan intensitas hujan diseluruh DAS.

Direktur Jenderal Sumber Daya Air mengatakan bahwa ada 20 kota rawan banjir di Indonesia, salah satunya yaitu Kota Palembang (https://www.viva.co.id, November 2018). Berdasarkan data dari Dinas Pekerjaan Umum Bina Marga dan Pengelolaan Sumber Daya Air Kota Palembang diketahui bahwa beberapa lokasi daerah di DAS Buah masuk kedalam 66 titik prioritas penanganan banjir di kota Palembang. Perubahan lahan sebanyak 25,74\% sepanjang tahun 2000-2017 telah menyebabkan beberapa daerah di DAS Buah mengalami banjir. Pada tahun 2017, terdapat 38 titik lokasi banjir di DAS Buah akibat reklamasi rawa dan pengurangan ruang terbuka hijau (Horisky dkk., 2018). Menurut Hoirisky dkk (2018), pada tahun 2017 ketinggian banjir di DAS Buah berkisar antara 20-70 cm dengan durasi banjir selama 2-8 jam. Kolam retensi yang telah dibangun Pemerintah Kota belum dapat menampung seluruh volume debit limpasan dan mengakibatkan luapan air ke pemukiman masyarakat. Salah satu penyebab tidak tertampungnya limpasan karena kapasitas kolam retensi eksisting yang tidak sesuai seperti yang terjadi pada KR Siti Khodijah (Al Amin, 2016), maupun kelayakan sarana dan prasarana kolam retensi yang belum memadai (Alia dkk., 2019).

Melihat dari kondisi permasalahan yang terjadi maka dibutuhkan suatu upaya pengendalian banjir, salah satunya adalah dengan merencanakan kolam retensi. Studi yang sama pernah dilakukan oleh Alia dkk. (2018) untuk pengendalian banjir di RSMH Kota Palembang. Pengendalian banjir merupakan kegiatan perencanaan, pelaksanaan pekerjaan pengendalian banjir, eksploitasi dan pemeliharaan, yang pada dasarnya untuk mengendalikan banjir, pengaturan penggunaan daerah dataran banjir dan mengurangi atau mencegah adanya bahaya atau kerugian akibat banjir (Kodoatie, 2013). Menurut (Kodoatie, 2013) kolam retensi berfungsi untuk menyimpan dan menampung air sementara dari saluran pembuangan sebelum dialirkan ke sungai sehingga puncak banjir dapat dikurangi. Tingkat pengurangan banjir tergantung pada karakteristik hidrograf banjir, volume kolam dan dinamika beberapa bangunan outlet.

Untuk mengatasi permasalahan banjir, Kepala Dinas Pekerjaan Umum dan Penataan Ruang (PUPR) Palembang memperkirakan bahwa 
dibutuhkan sebanyak 77 unit kolam retensi. Hingga tahun 2018, telah dibangun 34 kolam retensi di beberapa lokasi DAS yang mengalami banjir. Saat ini masih dibutuhkan 43 kolam retensi tambahan. Untuk menampung debit limpasan dan meredukasi banjir, selanjutnya akan dibangun 3 titik kolam retensi pada DAS Buah, yaitu di: Bukit Sangkal, Duku dan Sei Buah. Rencana ini juga terhimpun dalam RPI2JM (Rencana Sistem Prasarana Drainase) Kota Palembang Tahun 2016 - 2020.

Perencanaan kolam retensi di DAS Buah dilakukan dengan menganalisa kondisi eksisting menggunakan analisa hidrograf banjir HEC-HMS dan analisa spasial dengan Sistem Informasi Geografis. Selanjutnya simulasi kapasitas kolam retensi rencana dengan HEC-HMS dan SIG diharapkan dapat menurunkan debit puncak dalam usaha mencegah terjadinya banjir pada masa mendatang.

Kajian ini melingkupi: (a) analisis hidrologi DAS Buah untuk menentukan besarnya debit banjir rencana, (b) analisis kapasitas kolam retensi eksisting untuk menentukan titik lokasi rencana kolam retensi, dan (c) analisis kapasitas kolam retensi rencana sebagai upaya pengendalian banjir di DAS Buah, dengan melakukan pemodelan dengan HEC-HMS.

Berdasarkan hasil survei lapangan, selanjutnya akan diidentifikasi lokasi daerah topografi rendah atau cekungan yang dapat dimanfaatkan untuk kolam penampungan banjir. Daerah tersebut biasanya merupakan daerah yang tidak produktif. Di samping itu, kolam harus mempunyai head/energi yang cukup untuk mengalirkan sebagian banjir ke kolam (Kodoatie, 2013)

\section{Kriteria Hidrologi}

Permen PU No.12/PRT/M/2014 Tentang Penyelenggaraan Sistem Drainase Perkotaan akan digunakan sebagai dasar penetapan periode ulang untuk perencanaan kolam retensi berdasarkan luas daerah tangkapan hujan dan tipologi kota (Tabel 1). DAS Buah berada di Kota Palembang (Kota Metropolitan) dengan luas catchment area sebesar 1223,49 Ha,sehingga digunakan periode ulang 10 Tahun.

Tabel 1. Periode Ulang untuk Perencanaan Kolam Retensi

\begin{tabular}{lcccc}
\hline \multirow{2}{*}{ Tipologi Kota } & \multicolumn{5}{c}{ Catchment Area (Ha) } \\
& $<10$ & $10-100$ & $100-500$ & $>500$ \\
\hline Kota Metropolitan & 2 thn & $2-5$ thn & $5-10$ thn & $10-25$ thn \\
Kota Besar & 2 thn & $2-5$ thn & $2-5$ thn & $5-20$ thn \\
Kota Sedang/Kecil & 2 thn & $2-5$ thn & $2-5$ thn & $5-10$ thn \\
\hline
\end{tabular}

\section{Analisis Frekuensi}

Digunakan empat distribusi probabilitas antara lain: distribusi normal, distribusi log normal, distribusi gumbel dan distribusi log pearson III.

Distribusi normal banyak dipakai dalam analisis hidrologi, misal dalam analisis frekuensi curah hujan, analisis statistic dari distribusi rata-rata curah hujan tahunan, debit rata-rata tahunan, dan sebagainya. Distribusi normal sering disebut distribusi gauss. Persamaan distribusi normal yaitu:

$$
\mathrm{X}_{\mathrm{T}}=\bar{x}+\mathrm{K}_{\mathrm{Tr}} \mathrm{S}
$$

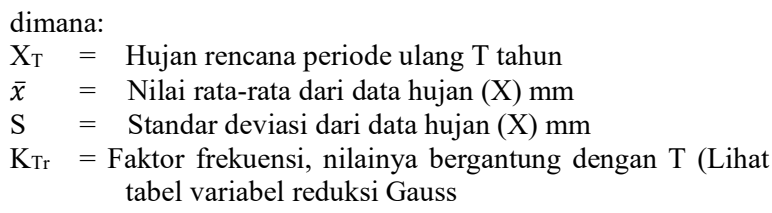

Hasil transformasi dari distribusi normal adalah Distribusi Log Normal. Pada distribusi ini setiap rangkaian data dikonversikan dalam bentuk logaritma $\mathrm{y}=\log \mathrm{x}$ untuk meramalkan nilai ekstrim. Jika $\mathrm{Cs} \approx 0$ dan $\mathrm{Cs} \approx 3 \mathrm{Cv}$ maka Distribusi Log Normal dapat dipakai. Metode distribusi log normal dapat dituliskan sebagai berikut:

$$
\begin{aligned}
& \log \mathrm{X}_{\mathrm{T}}=\overline{\log \mathrm{X}}+\mathrm{K}_{\mathrm{Tr}} \mathrm{S}_{\log } x \ldots \ldots \ldots \ldots \ldots \ldots \ldots \ldots \text { (2) } \\
& \mathrm{CV}=\frac{\mathrm{S} \log \bar{x}}{\log \bar{x}}
\end{aligned}
$$

dimana:

$\log X_{T}=$ Nilai logaritmis hujan rencana dengan periode ulang $\mathrm{T}$

$\log \bar{x}=$ Nilai rata-rata dalam logaritmik

$\mathrm{S}_{\mathrm{Log}} \bar{x}=$ Standar deviasi dalam logaritmik

$\mathrm{K}_{\mathrm{Tr}} \quad=$ Faktor frekuensi, nilainya tergantung $\mathrm{T}$

Distribusi Gumbel umumnya digunakan untuk analisis data maksimum. Distribusi ini dipakai jika $\mathrm{Cs} \approx 1,396$ dan $\mathrm{Ck} \approx 5,400$, dengan persamaan:

$$
\mathrm{X}_{\mathrm{T}}=\bar{x}+\frac{\mathrm{Y}_{\mathrm{T}}-\mathrm{Y}_{\mathrm{n}}}{\mathrm{S}_{\mathrm{n}}} \mathrm{S}
$$

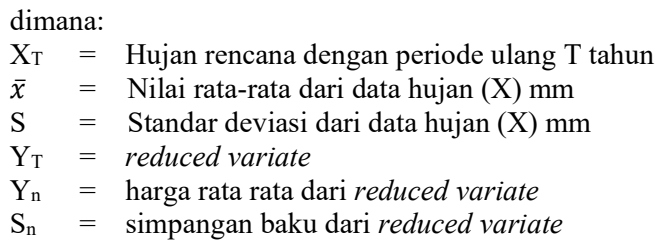

Nilai Yn dan Sn menunjukkan nilai tertentu pada jumlah data (n) tertentu. Harga reduced variate, $\mathrm{Y}_{\mathrm{T}}$ dihitung mengikuti persamaan:

$$
\mathrm{Y}_{\mathrm{T}}=-\ln \left(-\ln \frac{\mathrm{T}_{\mathrm{r}}-1}{\mathrm{~T}_{r}}\right) .
$$

dimana:

$\mathrm{Y}_{\mathrm{T}}=$ reduced variate

$\mathrm{T}_{\mathrm{r}}=$ jangka waktu ulang yang ditinjau 
Cantilever | Volume : 9 | Nomor : 2 | Oktober 2020 | ISSN: 1907-4247 (Print) | ISSN: 2477-4863 (Online)|Website: http://cantilever.id Febrinasti Alia dkk. | Analisis Kapasitas Kolam Retensi untuk Pengendalian Banjir di DAS Buah Kota Palembang

Distrbusi Log Pearson III digunakan dalam analisis data maksimum (banjir) dan minimum (debit minimum) dengan nilai ekstrim. Distribusi ini dipakai jika $\mathrm{Cs} \approx 0$ dan $\mathrm{Ck} \approx 4-6$. Dalam bentuk logaritma: $\mathrm{y}=\log \mathrm{x}$ data dikonversikan dengan faktor frekuensi tergantung dari periode $\mathrm{T}$ dan koefisien skewness (Cs). Apabila Cs $=0$, frekuensi mengikuti standar normal, yaitu variabel x. Apabila Cs $\neq 0$, persamaan distribusi Log Pearson type III mempunyai sebagai berikut :

$$
\log \mathrm{X}_{\mathrm{T}}=\overline{\log \mathrm{X}}+\mathrm{K}_{\mathrm{Tr}} \mathrm{S} \log x
$$

dimana:

$\log X_{\mathrm{T}}=$ Nilai logaritmis hujan rencana dengan periode ulang $\mathrm{T}$

$\log \bar{x}=$ Nilai rata-rata dalam logaritmik

$\mathrm{S}_{\mathrm{Log}} \bar{x}=$ Standar deviasi dalam logaritmik

$\mathrm{K}_{\operatorname{Tr}}=$ Faktor frekuensi, nilainya tergantung $\mathrm{T}$

\section{Uji Kecocokan}

Uji kecocokan dimaksudkan untuk mengetahui apakah persamaan distribusi probabilitas yang dipilih dapat mewakili distribusi statistik sampel data yang dianalisis. Metode Smirnov-Kolmogorov dan Chi Square digunakan untuk pengujian parameter. Metode Smirnov-Kolmogorov mencakup perbandingan antara probabilitas kumulatif aktual dilapangan dan distribusi kumulatif yang ditinjau. Prosedur pengujiannya adalah:

a) Mengurutkan data dari besar ke kecil.

b) Menentukan peluang empiris masing-masing data yang sudah diurut $\mathrm{P}\left(\mathrm{X}_{\mathrm{i}}\right)$ misalnya dengan rumus Weibull:

$$
\mathrm{P}\left(\mathrm{X}_{\mathrm{i}}\right)=\frac{\mathrm{n}+1}{\mathrm{I}}
$$

c) Berdasarkan persamaan distribusi probabilitas yang dipilih (Gumbel, Normal dan sebagainya). Ditentukan peluang teoritis dari $\mathrm{P}^{\prime}\left(\mathrm{X}_{\mathrm{i}}\right)$

d) Untuk setiap data yang sudah diurut, selisih $\left(\Delta \mathrm{P}_{\mathrm{i}}\right)$ antara peluang empiris dan teoritis dihitung:

$$
\Delta \mathrm{P}_{\mathrm{i}}=\mathrm{P}\left(\mathrm{X}_{\mathrm{i}}\right)-\mathrm{P}^{\prime}\left(\mathrm{X}_{\mathrm{i}}\right)
$$

e) Menentukan apakah $\Delta \mathrm{P}_{\mathrm{i}}>\Delta \mathrm{P}$ kritis, jika "iya" artinya distribusi probabilitas yang dipilih diterima, dan sebaliknya.

Pada metode Chi Square, distribusi probabilitas tidak dapat diterima apabila nilai Chi Square terhitung $\left(\mathrm{x}^{2}\right)$ lebih besar daripada Chi Square kritis $\left(\mathrm{x}_{\mathrm{cr}}^{2}\right)$. Persamaan yang digunakan adalah:

$$
x^{2}=\sum_{i=1}^{n} \frac{\left(\mathrm{O}_{\mathrm{f}}-\mathrm{E}_{\mathrm{f}}\right)^{2}}{\mathrm{E}_{\mathrm{f}}}
$$

$$
\begin{aligned}
\text { dimana: } & \\
x^{2}= & \text { Parameter Chi Square terhitung } \\
\mathrm{E}_{\mathrm{f}}= & \text { Frekuensi yang diharapkan sesuai dengan pembagian } \\
& \text { kelasnya }
\end{aligned}
$$

$\mathrm{O}_{\mathrm{f}}=$ Frekuensi yang diamati pada kelas yang sama

$\mathrm{n}=$ Jumlah sub kelompok

Derajat kepercayaan $(\alpha)$ yang diambil adalah $5 \%$, dengan derajat kebebasan (Dk) dihitung dengan:

$$
\begin{array}{ll}
\mathrm{Dk} & =\mathrm{K}-(\mathrm{p}+1) \ldots \\
\mathrm{K} & =1+3,3 \log \mathrm{n} .
\end{array}
$$

dimana:

$\mathrm{Dk}=$ Derajat kebebasan

$\mathrm{P} \quad=$ Banyaknya parameter, untuk Chi square $=2$

$\mathrm{K}=$ Jumlah kelas distribusi

$\mathrm{n} \quad=$ Banyaknya data

\section{Intensitas Curah Hujan}

Menurut (Triatmodjo, 2008) kedalaman air (mm) menyatakan jumlah hujan yang jatuh di permukaan bumi, hujan tersebut dianggap terdistribusi secara merata pada seluruh daerah tangkapan air. Rumus Mononobe dapat digunakan untuk menentukan intensitas curah hujan jika data hujan jangka pendek tidak terdapat pada stasiun. Persamaan Mononobe tersebut yaitu:

$$
\mathrm{I}=\frac{\mathrm{R}_{24}}{24}\left(\frac{24}{\mathrm{t}}\right)^{\frac{2}{3}}
$$

dimana:

I = Intensitas hujan ( $\mathrm{mm} / \mathrm{jam})$

$\mathrm{R}_{24}=$ Curah hujan maksimum harian selama 24 jam (mm)

$\mathrm{t} \quad=$ Lamanya hujan (jam)

\section{Metode SCS Curve Number}

Hujan yang menghasilkan limpasan merupakan fungsi dari hujan kumulatif, tata guna lahan, jenis tanah, serta kelembaban merupakan anggapan dari metode Soil Conservation Service (SCS) curve number $(C N)$. Metode ini dikembangkan oleh US Soil Conservation Service (SCS) pada tahun 1972. Potensi air yang melimpas untuk curah hujan tertentu ditunjukkan dengan besarnya nilai $\mathrm{CN}$, yaitu semakin kecil nilai $\mathrm{CN}$ maka semakin kecil potensi air hujan menjadi runoff.

Metode ini didasarkan atas hubungan infiltrasi pada setiap jenis tanah dengan jumlah curah hujan yang jatuh pada setiap hujan. Kedalaman curah hujan berlebih (depth excess rainfall) atau limpasan pemukaan ditentukan menggunakan Persamaan 13, dimana korelasi nilai Ia dengan S adalah:

$$
\begin{aligned}
& \mathrm{I}_{\mathrm{a}}=0,2 \mathrm{~S} \ldots \ldots \ldots \ldots \ldots \ldots \\
& \mathrm{S}=25,4\left(\frac{1000}{C N}-10\right) .
\end{aligned}
$$

dimana:

$\mathrm{CN}=$ Bilangan kurva air larian bervariasi dari 0 hingga 100

$\mathrm{I}_{\mathrm{a}}=$ Abstraksi awal (initial abstraction)

$\mathrm{S}=$ Volume dari total simpanan permukaan (mm) 
Dari nilai P dan Q pada kurva SCS, nilai CN dapat ditentukan. Metode SCS mengelompokkan jenis tanah dalam empat jenis, berdasarkan tipe tanah dan tataguna lahan(hydrology soil group). Pada abstraksi awal, digunakan pendekatan $0.2 \mathrm{~S}$ sehingga persamaan menjadi:

$$
Q=\frac{(P-0,2 S)^{2}}{(P-0,8 S)}
$$

\section{Hidrograf Metode SCS}

Perhitungan Hidrograf SCS menggunakan persamaan:

$$
\begin{aligned}
& \mathrm{t}_{\mathrm{L}}=\frac{\mathrm{L}^{0,8}+(\mathrm{S}+1)^{0,7}}{1900 . \mathrm{Y}^{0,5}} \\
& \text { tc }=\frac{5}{3} \times \mathrm{T}_{\mathrm{L}} \\
& \mathrm{t}_{\mathrm{r}}=0,6 \mathrm{Tc} \text {. } \\
& \mathrm{t}_{\mathrm{p}} \quad=\frac{1}{2} \mathrm{tr}+\mathrm{tp} \\
& \mathrm{Qp}_{\mathrm{p}}=\frac{0,208 \mathrm{~A}}{P_{r}} \\
& \operatorname{Pr}_{\mathrm{r}}=\frac{t_{r}}{2}+t_{p} \text {. }
\end{aligned}
$$

dimana:

$t_{\mathrm{L}}=$ Waktu jeda $\mathrm{t}_{\mathrm{c}}=$ Waktu konsentrasi

$\mathrm{t}_{\mathrm{r}}=$ Durasi hujan $\mathrm{t}_{\mathrm{p}}=$ Lag time

$\mathrm{T}_{\mathrm{p}}=$ Waktu naik $\quad \mathrm{Q}_{\mathrm{p}}=$ Debit Puncak

\section{METODOLOGI PENELITIAN}

\section{Lokasi Penelitian}

Penelitian ini berlokasi di DAS Buah Kota Palembang. DAS Buah ini dari hulu ke hilir terbentang seluas 1223 Ha. Kawasan penelitian masuk dalam wilayah 3 Kecamatan, yaitu: Kecamatan Ilir Timur II, Kecamatan Kalidoni dan Kecamatan Sako. DAS Borang, DAS Juaro, DAS Bendung dan DAS Kidul berbatasan langsung dengan DAS Buah (Gambar 1).

Terdapat 6 kolam retensi eksisting pada DAS Buah, yaitu: kolam retensi Kiwal, kolam retensi PLN Sapta Marga, kolam retensi Citra Damai, kolam retensi Citra Damai II, kolam retensi Kedamaian dan kolam retensi Arafuru.

\section{Tahapan Penelitian}

Tahap awal dilakukan dengan studi literatur, selanjutnya pengumpulan data berupa data primer dan data sekunder (Gambar 2). Data primer berupa initial conditions dari kolam retensi eksisting, mencakup bentuk geometri dan muka air dari kolam retensi. Pengambilan data dilakukan dengan cara pemeruman kolam retensi eksisting dengan alat echosounder Garmin 580 plus. Data sampel tanah diteliti di laboratorium untuk mengetahui karakteristik tanah di lokasi penelitian.

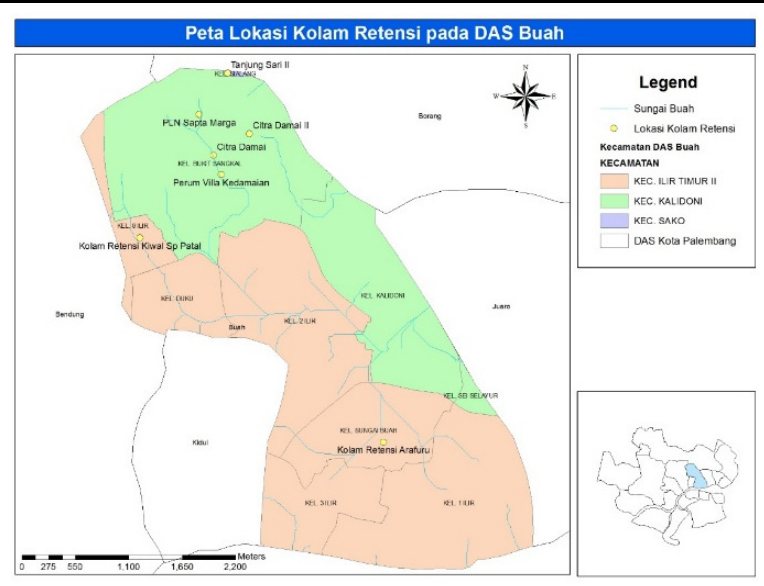

Gambar 1. Lokasi kolam retensi DAS Buah

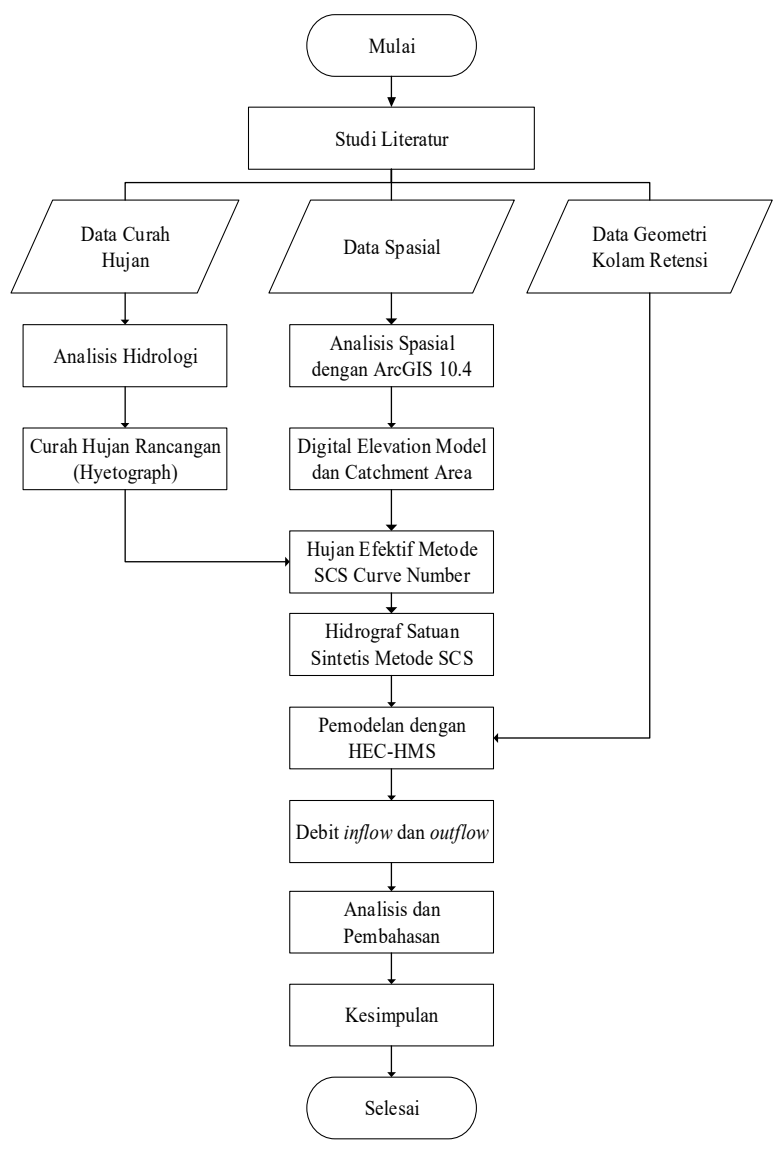

Gambar 2. Diagram alir penelitian

Data sekunder yang diambil dari Badan Meteorologi, Klimatologi dan Geofisika (BMKG) mencakup data curah hujan harian maksimum selama 10 tahun terakhir. Peta rencana tata ruang wilayah (RTRW), peta kontur, peta lokasi kolam retensi eksisting, dan peta tematik lainnya bersumber dari Bappeda Kota Palembang.Data genangan banjir (titik lokasi, lama, kedalaman ratarata, frekuensi genangan)pada daerah studi, didapat dari Dinas Pekerjaan Umum dan Penataan Ruang (PUPR) Kota Palembang. 
Cantilever | Volume : 9 | Nomor : 2 | Oktober 2020 | ISSN: 1907-4247 (Print) | ISSN: 2477-4863 (Online)|Website: http://cantilever.id Febrinasti Alia dkk. | Analisis Kapasitas Kolam Retensi untuk Pengendalian Banjir di DAS Buah Kota Palembang

\section{Tahapan Analisis Data}

Dalam penelitian ini tahapan analisis yang dilakukan antara lain:

1) Analisis Frekuensi dan Uji Kecocokan metode Distribusi Normal, Log Normal, Log Pearson III dan Gumbel. Uji kecocokan dengan metode Simrnov-kolmogorov dan Chi Square.

2) Perhitungan intensitas curah hujan dan kurva IDF (Intensity Duration Frequency)

3) Menggunakan metode Mononobe Modifikasi sehingga didapat Distribusi Curah Hujan Rancangan (hyetograph).

4) Pembuatan DEM (digital elevation model) dan pembagian catchment area dengan analisis spasial.

5) Analisis Jenis Tanah mengacu kepada SNI 6371:2015. Untuk menentukan kelompok tanah menurut curve number.

6) Hubungan antaran elevasi dan luas kolam retensi dalam bentuk grafik, dan pengumpulan data primet initial conditions.

7) Pembuatan Hidrograf Satuan Sintetis SCS sebagai data masukan pemodelan hidrograf limpasan langsung pada HEC-HMS.

8) Pemodelan DAS dengan HEC-HMS 4.3 untuk mendapatkan debit puncak masing-masing catchment area.

9) Analisa citra satelit dari Google Earth dan dijitasi dengan ArcGIS untuk menentukan alternatif titik lokasi kolam retensi rencana.

10) Kolam Retensi Rencana dimodelkan dengan HEC-HMS dengan pendekatan hidrograf SCS untuk mendapat debit inflow dan outflow kolam retensi.

11) Menganalisis pengaruh debit inflow terhadap elevasi muka air untuk menetapkan kedalaman minimum kolam retensi.

12) Menganalisis kemampuan kolam retensi dalam mereduksi debit puncak $\left(\mathrm{Q}_{\mathrm{p}}\right)$ dilihat berdasarkan presentase reduksi debit inflow dan outflow untuk mengetahui Efektifitas Kolam Retensi

Output hasil analisa diatas berupa koordinat lokasi kolam retensi rencana, luas kolam retensi rencana, kedalaman minimum kolam retensi rencana dan presentase reduksi banjir dari kolam retensi rencana.

\section{ANALISIS DAN PEMBAHASAN}

\section{Analisis Frekuensi}

Mengingat banjir merupakan kejadian ekstrim, maka digunakan curah hujan harian maksimum. Data curah hujan yang digunakan didapat dari BMKG stastiun Kenten dari tahun 2010 - 2019 (Gambar 3). Analisis frekuensi menggunakan curah hujan maksimum tahunan, dan dilakukan dengan 4 jenis distribusi frekuensi, yaitu: distribusi Normal, distribusi Log Normal, distribusi Log Person tipe III, dan distribusi Gumbel (Tabel 2).

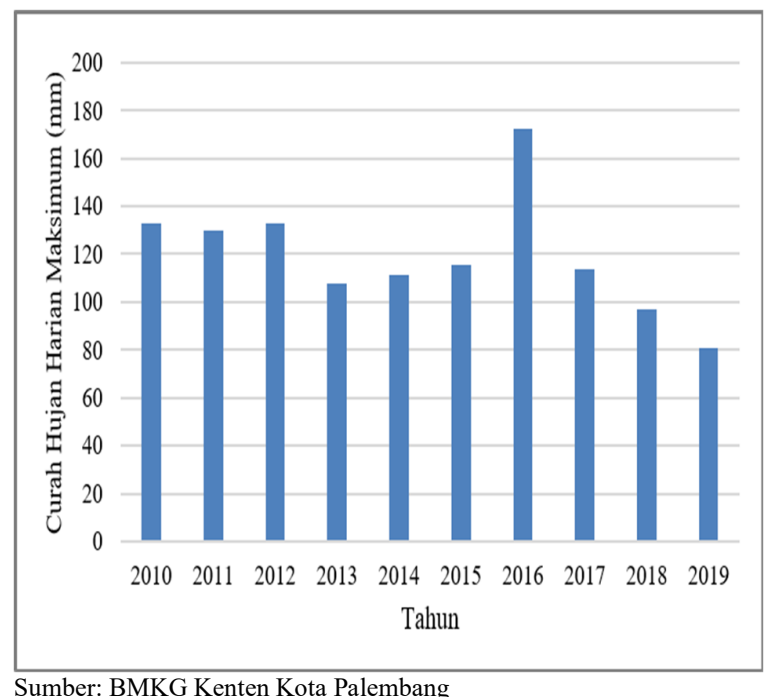

Gambar 3. Curah Hujan Maksimum Tahunan

Tabel 2. Analisis Frekuensi Curah Hujan Rencana

\begin{tabular}{ccccc}
\hline \multirow{2}{*}{$\begin{array}{c}\text { Periode Ulang } \\
\text { (Tahun) }\end{array}$} & \multicolumn{4}{c}{ Distribusi Probabilitas (mm) } \\
\cline { 2 - 5 } & Normal & Gumbel & Log Normal & Log Person III \\
\hline 2 & 119,400 & 116,033 & 117,15 & 116,98 \\
5 & 140,271 & 145,690 & 139,21 & 139,19 \\
10 & 151,204 & 165,325 & 152,37 & 152,56 \\
25 & 160,149 & 190,134 & 164,06 & 168,32 \\
50 & 170,336 & 208,539 & 178,47 & 179,41 \\
100 & 177,293 & 226,808 & 189,03 & 190,05 \\
\hline
\end{tabular}

Uji kecocokan Chi Square dan Uji SmirnovKolmogorov dilakukan untuk mengujidistribusi yang paling mewakili. Dari hasiluji kecocokan chisquare, keempat distribusi probabilitas dapat diterima karena memiliki $\mathrm{x}^{2}$ yang lebih kecil dari $\mathrm{x}^{2}$ kritik(Tabel3).Berdasarkan uji kecocokan,digunakan Distribusi Log Normal pada perhitungan berikutnya, karena memiliki nilai $\Delta_{\text {maks }}$ dan nilai $\alpha$ terkecil.

\section{Kurva IDF}

Kurva IDF metode Mononobe (Gambar 4) menggambarkan hubungan antara intensitas, durasi, dan frekuensi (IDF), yang menggambarkan intensitas hujan dengan durasi setiap 5 menit pada periode ulang.

Tabel 3. Hasil Uji Kecocokan

\begin{tabular}{lcccc}
\hline \multirow{2}{*}{ Distribusi } & \multicolumn{4}{c}{ Distribusi Probabilitas } \\
\cline { 2 - 5 } & \multicolumn{2}{c}{ Chi Square } & \multicolumn{2}{c}{ Smirnov-Kolmogorov } \\
& $\alpha$ & $\Delta_{\text {maks }}$ & $\Delta_{\text {maks }}$ & Uji Kecocokan \\
\hline Normal & 1,00 & 0,11 & 0,11 & Diterima \\
Log Normal & 1,00 & 0,086 & 0,086 & Diterima \\
Gumbell & 2,00 & 0,097 & 0,097 & Diterima \\
Log Pearson III & 4,00 & 0,119 & 0,119 & Diterima \\
\hline \multicolumn{1}{c}{ Nilai Terkecil } & 1,00 & 0,086 & 0,086 & \\
\hline
\end{tabular}

Attribution-NonCommercial 4.0 International. Some rights reserved 


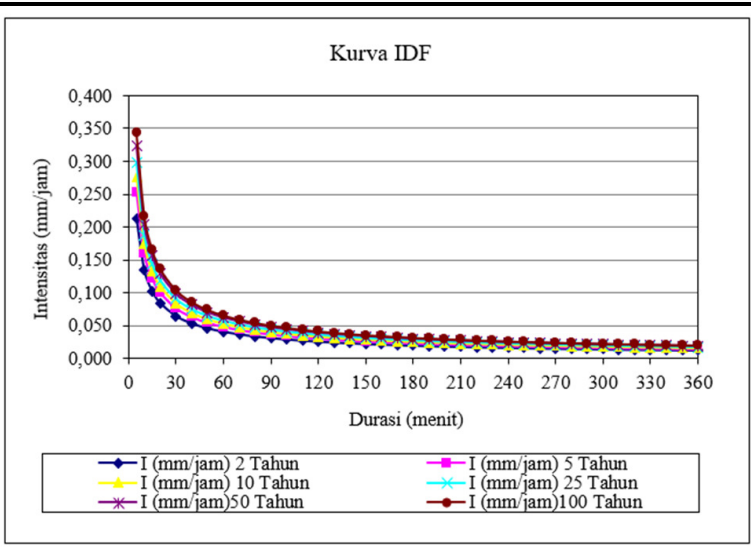

Gambar 4. Kurva IDF

\section{Distribusi Curah Hujan Rancangan}

Metode Mononobe Modifikasi dengan memperhitungkan debit limpasan banjir rancangan digunakan untuk distribusi curah hujan rancangan ke dalam kedalaman hujan per jam atau per menit (hyetograph) dengan (Gambar 5).

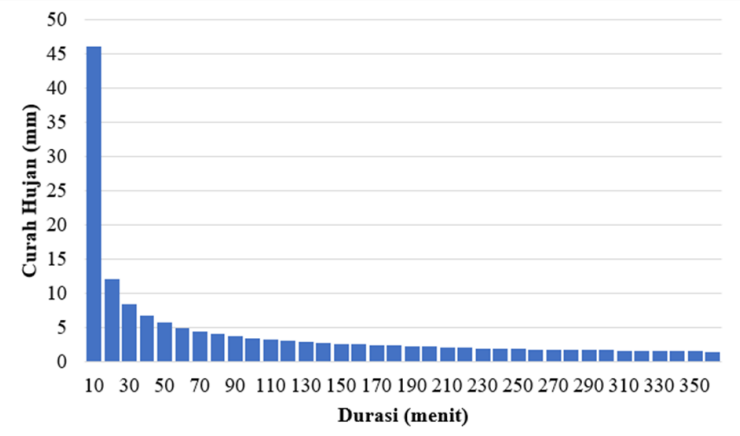

Gambar 5. Hyetograph Mononobe Modifikasi periode ulang 10 Tahun

\section{Digital Elevation Model (DEM)}

Data kontur bersumber dari BAPEDDA Kota Palembang digunakan sebagai input data yang kemudian dimodelkan dengan ArcGIS (Gambar 6) untuk memperoleh Digital elevation model (DEM). Diketahui bahwa elevasi DAS Buah berkisar antara 0,659 mdpl - 24,069 mdpl.

\section{Catchment Area DAS Buah}

Watershed delineation pada DEM di ArcGIS 10.5 digunakan untuk menentukan catchment area (Gambar 7). Dari hasil pemodelan, didapat bahwa DAS Buah terdiri dari 26 catchment area. Nilai curve number dapat dicari dengan menggunakan data tutupan lahan dari catchment area. Dari pemodelan ini, juga didapatkan data keluaran berupa aliran sungai yang mengaliri DAS Buah.

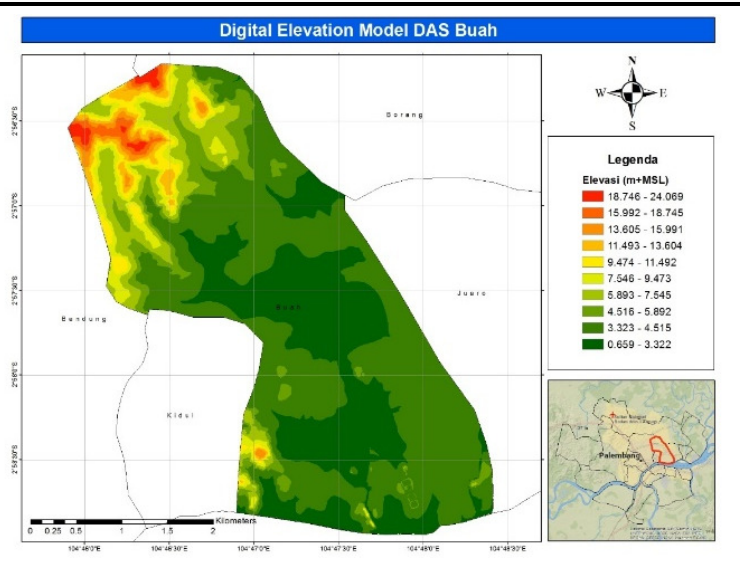

Gambar 6. Digital elevation model (DEM) DAS Buah

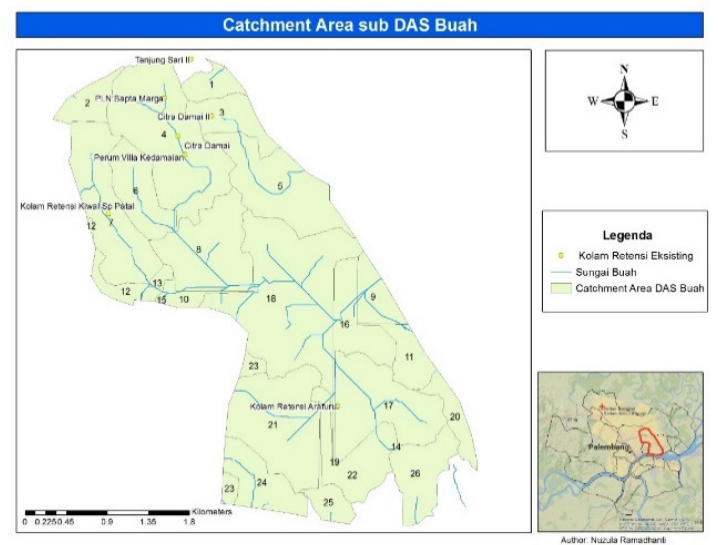

Gambar 7. Pembagian catchment area DAS Buah

\section{Tutupan Lahan pada Catchment Area}

Klasifikasi peta tata guna lahan yang bersumber dari BAPPEDA Kota Palembang digunakan sebagai dasar perhitungan dengan metode curve number (Gambar 8). Analisa spasial untuk memperoleh klasifikasi dan luas tutupan lahan pada catchment area dilakukan dengan SIG.

\section{Analisis Jenis Tanah}

Untuk mengetahui jenis tanah dalam menentukan nilai curve number, didapat hasil pengujian sampel tanah DAS Buah di laboratorium (SNI 6371:2015), tanah termasuk kedalam jenis tanah lanau elastis. Menurut Triajmodjo (2008), tanah lanau elastis (silty clay loam) termasuk kedalam kelompok tanah D dengan laju infiltrasi minimum (fc) $2,3 \mathrm{~mm} / \mathrm{jam}$.

\section{Hidrografi Kolam Retensi Eksisting}

Dari analisis kedalaman 6 kolam retensi eksisting, yang didapat dari data pemeruman menggunakan alat echosounder merk Garmin 580 plus dengan interpolasi titik pada ArcGIS. Sebagai contoh pada kolam retensi Kiwal, kolam tersebut memiliki kedalaman berkisar $0,513-2,34 \mathrm{~m}$ dengan tinggi talud 2,7 $\mathrm{m}$, dan tinggi jagaan $\pm 0,5 \mathrm{~m}$ (Gambar 9). 
Cantilever | Volume : 9 | Nomor : 2 | Oktober 2020 | ISSN: 1907-4247 (Print) | ISSN: 2477-4863 (Online)|Website: http://cantilever.id Febrinasti Alia dkk. | Analisis Kapasitas Kolam Retensi untuk Pengendalian Banjir di DAS Buah Kota Palembang

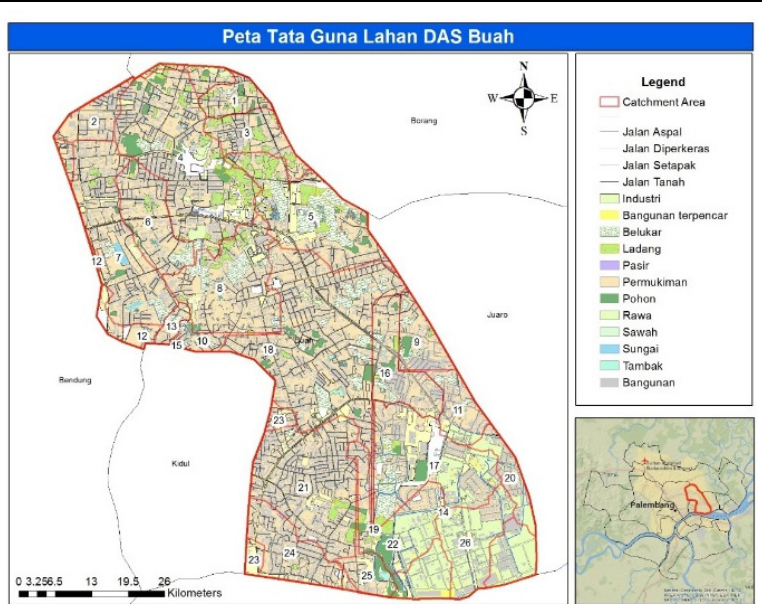

Gambar 8. Peta Tata Guna Lahan DAS Buah

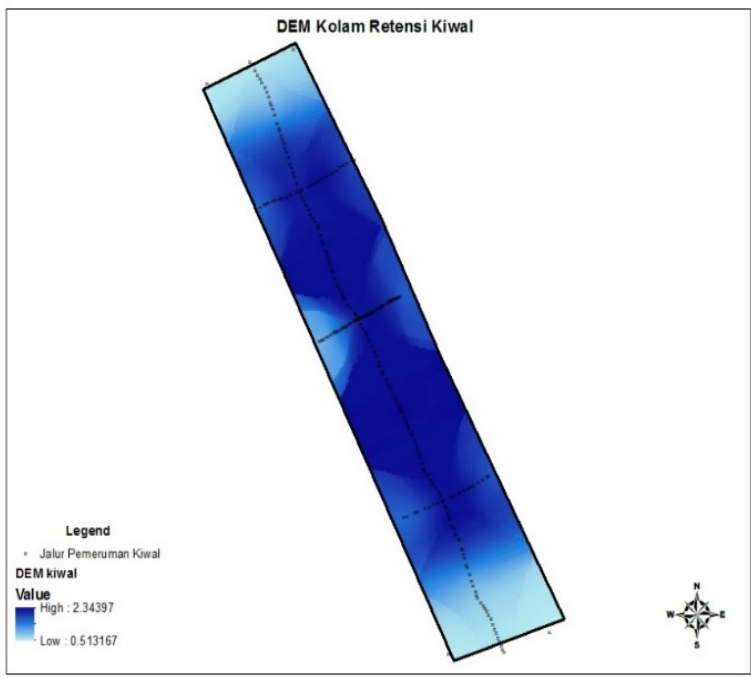

Gambar 9. DEM Kolam Retensi Kiwal

Menggunakan tool reclassify pada ArcGIS dilakukan analisis lereng kolam retensi sehingga diketahui bahwa elevasi puncak kolam adalah 2,34 m, dengan luasan kolam sebesar 2,156 Ha. Korelasi antara elevasi dengan luasan permukaan air di dalam kolam dapat dilihat pada Gambar 10.

\section{Curve Number dan Presentase Kedap Air}

Perhitungan nilai Curve Number (CN) didasarkan pada luas, tutupan lahan, dan karakteristik tanah pada daerah tangkapan hujan. Nilai CN didasarkan pada ketentuan SCS (Triatmodjo, 2008). Berdasarkan Tabel 4, didapat nilai $\mathrm{CN}$ rerata sebesar $1550,58 / 18,114=85,601$. Nilai CN komposit didapat sebesar 93 dari grafik hubungan antara presentase luas kedap air dan $\mathrm{CN}$ rerata.

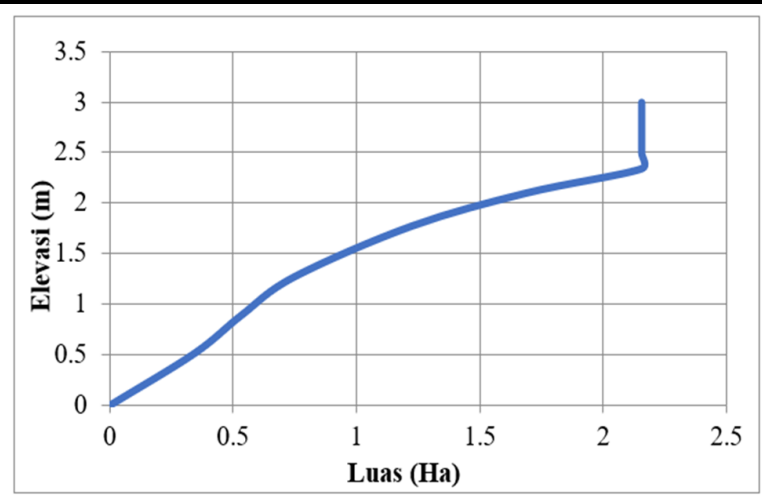

Gambar 10. Hubungan Antara Elevasi dan Luas Kolam Retensi Kiwal

Tabel 4 Nilai $C N$ dan Presentase Kedap Air catchment area 1

\begin{tabular}{cccccc}
\hline $\begin{array}{c}\text { Jenis Tutupan } \\
\text { Lahan }\end{array}$ & A (Ha) & CN & A x CN & $\begin{array}{c}\text { \% Imp } \\
\text { Lahan }\end{array}$ & $\begin{array}{c}\text { \%uas } \\
\text { Kedap Air }\end{array}$ \\
\hline Tambak & 0,018 & 77 & 1,386 & 0 & 0,0000 \\
Pohon & 0,927 & 83 & 76,941 & 5 & 0,2559 \\
Belukar & 0,963 & 78 & 75,114 & 2 & 0,1063 \\
Rawa & 0,180 & 77 & 13,86 & 2 & 0,0199 \\
Ladang & 2,593 & 91 & 235,963 & 2 & 0,2863 \\
Permukiman & 12,080 & 84 & 1014,72 & 85 & 56,6854 \\
Jalan Aspal & 1,353 & 98 & 132,594 & 100 & 7,4694 \\
\hline Total & 18,114 & & 1550,58 & & 64,8232 \\
\hline
\end{tabular}

Perhitungan nilai retensi potensial maksimum (S) dihitung menggunakan persamaan berikut:

$$
\mathrm{S}=\frac{25400}{\overline{C N}}-254=\frac{25400}{93}-254=19,118 \mathrm{~mm}
$$

Berdasarkan nilai $\mathrm{S}$ yang di dapat, maka dapat dihitung nilai abstraksi awal sebagai berikut :

$$
\mathrm{I}_{\mathrm{a}}=0,20 \times \mathrm{S}=0,20 \times 19,1180 \mathrm{~mm}=3,8240 \mathrm{~m}
$$

Rekapitulasi perhitungan parameter hujan efektif adalah (Tabel 5):

\section{Hidrograf Satuan Sintetis Metode SCS}

Hasil perhitungan komponen HSS SCS berupa waktu jeda $\left(T_{L}\right)$ dan waktu konsentrasi $\left(T_{c}\right)$ menjadi data masukan dalam HEC-HMS. Pada subDAS 1, diketahui debit puncak sebesar $0,388 \mathrm{~m}^{3} / \mathrm{s}$,yang dicapai pada menit ke 6,6. Hidrograf untuk subDAS 1 terlihat dalam Gambar 11.

Pada Tabel 6, dapat dilihat hasil perhitungan panjang saluran utama (L), kemiringan lahan ratarata $(\mathrm{Y})$, luas catchment area $(\mathrm{A})$, waktu jeda $\left(\mathrm{T}_{\mathrm{L}}\right)$, waktu konsentrasi $\left(\mathrm{T}_{\mathrm{c}}\right)$, durasi hujan $\left(\mathrm{T}_{\mathrm{r}}\right)$, dan debit puncak $\left(\mathrm{Q}_{\mathrm{p}}\right)$ untuk catchment area lainnya pada DAS Buah. 
Tabel 5. Rekapitulasi Perhitungan Parameter Hujan Efektif

\begin{tabular}{ccccccc}
\hline $\begin{array}{c}\text { Sub } \\
\text { DAS }\end{array}$ & $\begin{array}{c}\text { A } \\
\left(\mathrm{km}^{2}\right)\end{array}$ & $\begin{array}{c}\mathrm{L} \\
(\mathrm{km})\end{array}$ & CN & \% Imp & $\begin{array}{c}\text { S } \\
(\mathrm{mm})\end{array}$ & $\begin{array}{c}\text { Ia } \\
(\mathrm{mm})\end{array}$ \\
\hline 1 & 0,181 & 0,362 & 93 & 64,823 & 19,118 & 3,824 \\
\hline 2 & 0,215 & 0,329 & 95 & 77,498 & 13,368 & 2,674 \\
\hline 3 & 0,316 & 0,361 & 93 & 62,191 & 19,118 & 3,824 \\
\hline 4 & 1,327 & 1,816 & 90 & 35,330 & 28,222 & 5,644 \\
\hline 5 & 0,842 & 1,306 & 89 & 38,132 & 31,393 & 6,279 \\
\hline 6 & 0,448 & 0,363 & 93 & 66,479 & 19,118 & 3,824 \\
\hline 7 & 0,858 & 1,265 & 93 & 68,447 & 19,118 & 3,824 \\
\hline 8 & 0,798 & 1,095 & 92 & 57,061 & 22,087 & 4,417 \\
\hline 9 & 0,251 & 0,301 & 95 & 70,434 & 13,368 & 2,674 \\
\hline 10 & 0,103 & 0,982 & 92 & 59,049 & 22,087 & 4,417 \\
\hline 11 & 0,245 & 0,317 & 92 & 55,269 & 22,087 & 4,417 \\
\hline 12 & 0,130 & 0,254 & 93 & 57,639 & 19,118 & 3,824 \\
\hline 13 & 0,067 & 0,182 & 92 & 56,147 & 22,087 & 4,417 \\
\hline 16 & 0,431 & 1,577 & 93 & 63,614 & 19,118 & 3,824 \\
\hline 17 & 0,879 & 0,721 & 90 & 35,641 & 28,222 & 5,644 \\
\hline 18 & 1,707 & 2,229 & 93 & 66,038 & 19,118 & 3,824 \\
\hline 20 & 0,195 & 0,330 & 88 & 39,430 & 34,636 & 6,927 \\
\hline 21 & 0,999 & 1,119 & 94 & 71,029 & 16,213 & 3,243 \\
\hline 22 & 0,490 & 0,272 & 88 & 33,618 & 34,636 & 6,927 \\
\hline 24 & 0,411 & 0,259 & 94 & 70,544 & 16,213 & 3,243 \\
\hline 25 & 0,174 & 0,435 & 88 & 39,960 & 34,636 & 6,927 \\
\hline 26 & 0,447 & 1,014 & 87 & 20,457 & 37,954 & 7,591 \\
\hline & & & & & &
\end{tabular}

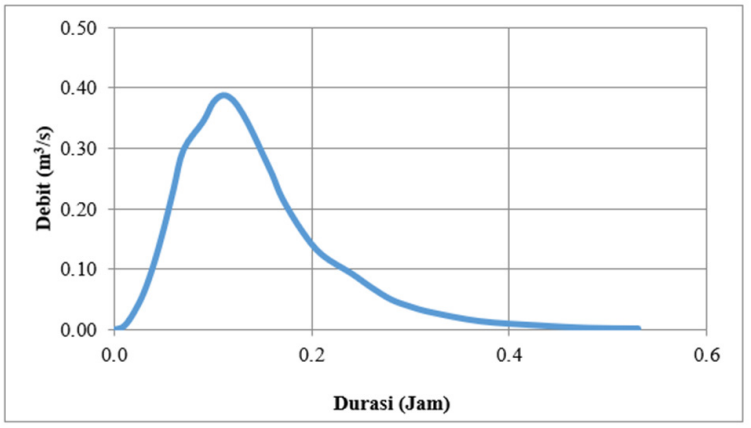

Gambar 11. Hidrograf SCS subDAS 1

\section{Pemodelan DAS Buah dengan HEC-HMS}

Pemodelan dengan HEC-HMS bertujuan untuk memodelkan hidrologi DAS Buah dengan menggunakan kondisi batas dan initial condition yang telah diperoleh baik dari hasil analisa maupun survey lapangan. Simulasi Basin Model dilakukan untuk dua skenario yaitu skenario eksisting pada 6 kolam retensi dan simulasi kedua yaitu pengendalian banjir dengan penambahan beberapa alternatif lokasi kolam retensi rencana dengan tujuan mereduksi debit puncak. Periode ulang 10 tahun digunakan pada skenario eksisting (untuk kota metropolitan dengan luas tangkapan lebih dari 500 Ha)

\section{Hasil Simulasi HEC-HMS}

Dari hasil simulasi HEC-HMS didapatkan hidrograf limpasan pada catchment area berupa debit masuk dan debit keluar kolam retensi serta elevasi muka air kolam retensi, dapat dibandingkan elevasi puncak dari HEC-HMS dan elevasi talud hasil survey. Hasil analisis untuk sub DAS kolam retensi Kiwal menggunakan program HEC-HMS dapat dilihat pada Gambar 13.

Tabel 6. Rekapitulasi Perhitungan Komponen HSS SCS

\begin{tabular}{cccccccc}
\hline $\begin{array}{c}\text { Sub } \\
\text { DAS }\end{array}$ & $\begin{array}{c}\mathrm{Y} \\
\%\end{array}$ & $\begin{array}{c}\mathrm{T}_{\mathrm{L}} \\
\text { jam }\end{array}$ & $\begin{array}{c}\mathrm{Tc} \\
\text { jam }\end{array}$ & $\begin{array}{c}\mathrm{Tr} \\
\mathrm{min}\end{array}$ & $\begin{array}{c}\mathrm{Tp} \\
\mathrm{min}\end{array}$ & $\begin{array}{c}\mathrm{Qp} \\
\mathrm{m}^{3} / \mathrm{s}\end{array}$ & $\begin{array}{c}\mathrm{Pr} \\
\text { jam }\end{array}$ \\
\hline 1 & 3,04 & 0,087 & 0,146 & 0,019 & 0,097 & 0,388 & 0,107 \\
2 & 3,64 & 0,074 & 0,124 & 0,016 & 0,082 & 0,544 & 0,091 \\
3 & 0,83 & 0,167 & 0,278 & 0,037 & 0,185 & 0,354 & 0,204 \\
4 & 0,17 & 1,339 & 2,232 & 0,297 & 1,487 & 0,186 & 1,636 \\
5 & 0,08 & 1,500 & 2,501 & 0,333 & 1,666 & 0,105 & 1,833 \\
6 & 0,83 & 0,168 & 0,280 & 0,037 & 0,186 & 0,499 & 0,205 \\
7 & 0,24 & 0,844 & 1,407 & 0,187 & 0,938 & 0,190 & 1,032 \\
8 & 0,09 & 1,228 & 2,047 & 0,272 & 1,365 & 0,122 & 1,501 \\
9 & 0,33 & 0,229 & 0,382 & 0,051 & 0,255 & 0,205 & 0,280 \\
10 & 0,10 & 1,069 & 1,781 & 0,237 & 1,187 & 0,018 & 1,306 \\
11 & 0,32 & 0,243 & 0,405 & 0,054 & 0,270 & 0,189 & 0,297 \\
12 & 2,36 & 0,075 & 0,125 & 0,017 & 0,083 & 0,323 & 0,092 \\
13 & 1,10 & 0,084 & 0,141 & 0,019 & 0,094 & 0,148 & 0,103 \\
16 & 0,06 & 2,014 & 3,356 & 0,446 & 2,237 & 0,040 & 2,460 \\
17 & 0,28 & 0,499 & 0,831 & 0,111 & 0,554 & 0,330 & 0,610 \\
18 & 0,04 & 3,251 & 5,418 & 0,721 & 3,611 & 0,098 & 3,972 \\
20 & 0,30 & 0,259 & 0,432 & 0,057 & 0,288 & 0,141 & 0,316 \\
21 & 0,18 & 0,884 & 1,473 & 0,196 & 0,982 & 0,213 & 1,080 \\
22 & 0,74 & 0,436 & 0,727 & 0,097 & 0,485 & 0,210 & 0,533 \\
24 & 0,17 & 0,283 & 0,472 & 0,063 & 0,315 & 0,271 & 0,346 \\
25 & 0,69 & 0,213 & 0,355 & 0,047 & 0,236 & 0,153 & 0,260 \\
26 & 0,20 & 0,775 & 1,292 & 0,172 & 0,861 & 0,108 & 0,947 \\
\hline
\end{tabular}

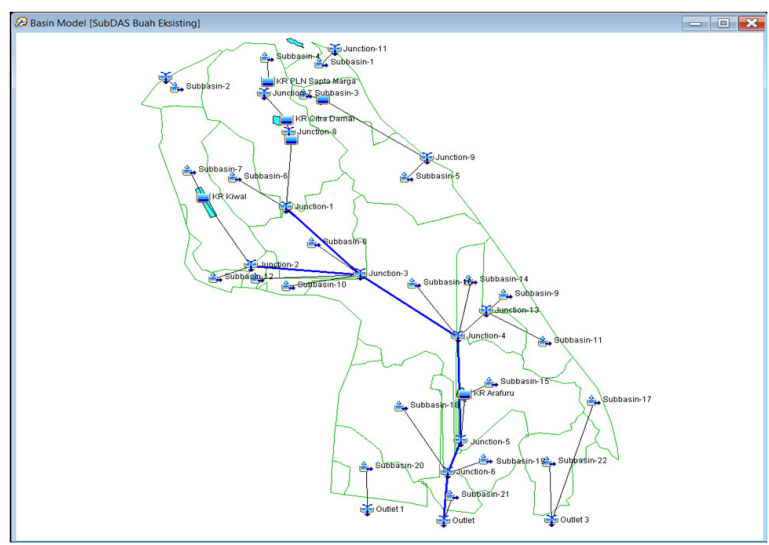

Gambar 12. Basin Model DAS Buah Eksisting

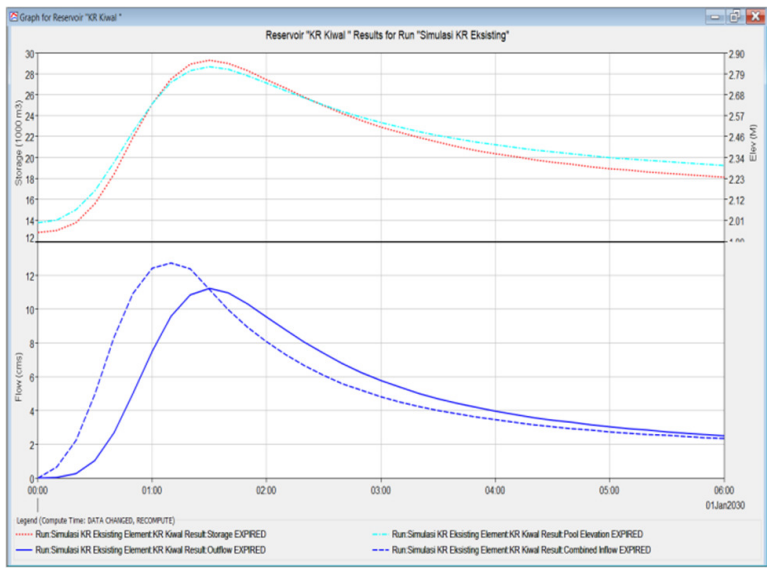

Gambar 13. Grafik Elevasi vs Tampungan dan Hidrograf Kolam Retensi Kiwal 
Berdasarkan hasil pemodelan dengan HEC-HMS diketahui kolam retensi Kiwal akan menerima debit masuk puncak (inflow) sebesar $12,76 \mathrm{~m}^{3} /$ det. Waktu yang dibutuhkan untuk mencapai debit puncak tersebut yaitu 60 menit. Selanjuntya debit mengalami penurunan setelah 90 menit menjadi $11,26 \mathrm{~m}^{3} /$ det. Volume kebutuhan tampungan limpasan sebesar $29.320 \mathrm{~m}^{3}$ dan elevasi puncak 2,83m (elevasi muka air melebihi elevasi talud sekitar $60 \mathrm{~cm}$ ) maka terdapat potensi genangan disekitar kolam. Dilakukan prosedur analisa yang sama terhadap kelima kolam lainnya (Tabel 7).

Tabel 7. Rekapitulasi Hasil Analisis Kolam Retensi Eksisting

\begin{tabular}{ccccc}
\hline Kolam Retensi & $\begin{array}{c}\text { Luas } \\
(\mathrm{Ha})\end{array}$ & $\begin{array}{c}\text { Zlevasi } \\
\text { Talud } \\
(\mathrm{m})\end{array}$ & $\begin{array}{c}\text { Elevasi } \\
\text { Puncak } \\
\text { Muka Air } \\
(\mathrm{m})\end{array}$ & Keterangan \\
\hline PLN Sapta Marga & 0,087 & 2 & 2,20 & Melimpas \\
Citra Damai & 1,359 & 2,1 & 2,19 & Melimpas \\
Kedamaian & 0,135 & 2 & 2,19 & Melimpas \\
Kiwal & 2,156 & 2,2 & 2,83 & Melimpas \\
Citra Damai II & 0,195 & 2 & 2,73 & Melimpas \\
Arafuru & 0,962 & 2,3 & 2,96 & Melimpas \\
\hline
\end{tabular}

Dari analisis dapat disimpulkan bahwa pada periode ulang 10 tahun kolam retensi tersebut tidak mampu menampung debit inflow dari catchment area. Sebagai solusi, dilakukan analisis rencana beberapa alternatif lokasi kolam retensi..

\section{Analisis Lokasi Kolam Retensi Rencana}

Berdasarkan hasil analisis dengan citra satelit Google Earth dan ArcGIS didapatkan alternatif lokasi kolam retensi rencana dengan kriteria ketersediaan lahan, luas lahan, topografi dan presentase reduksi debit banjir, didapatkan 12 alternatif kolam retensi rencana. Salah satunya adalah kolam retensi Sabokingking. Kolam retensi Sabokingking seluas 2,162 Ha berlokasi di Jalan Makam Sabokingking pada koordinat $104,792^{\circ}$ LS dan $-2,975^{\circ}$ LT. Lokasi kolam retensi ini berada disamping sungai Buah yang merupakan lahan kosong dengan tutupan lahan berupa rumput dan pepohonan dengan elevasi 3mdpl (Gambar 14). Rekapitulasi dari hasil analisis semua lokasi kolam retensi tersaji dalam Tabel 8. Data tersebut dijadikan data masukan untuk pemodelan kolam retensi rencana.

Pemodelan HEC-HMS Kolam Retensi Rencana Dalam melakukan pemodelan dengan HEC-HMS, dilakukan peniruan kondisi DAS eksisting dengan menambahkan elemen reservoir yang mewakili kolam retensi rencana (Gambar 15). Elevasi dan luas kolam menjadi data masukan pada kolam retensi rencana dengan asumsi tampungan awal kolam retensi setelah dibangun adalah $1 \mathrm{~m}$.

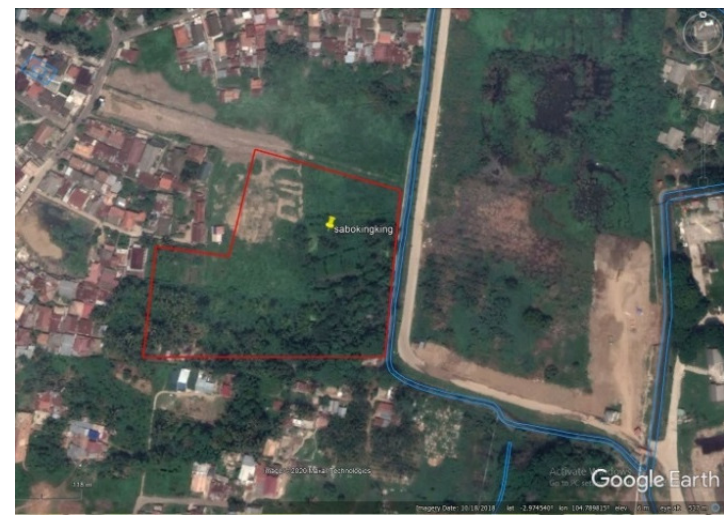

Gambar 14. Lokasi kolam retensi rencana Sabokingking

Tabel 8. Rekapitulasi Hasil Analisis Kolam Retensi Eksisting

\begin{tabular}{|c|c|c|c|c|}
\hline \multirow[t]{2}{*}{ No. } & \multirow{2}{*}{$\begin{array}{l}\text { Nama Kolam } \\
\text { Retensi }\end{array}$} & \multicolumn{2}{|c|}{ Luas Kolam Jenis Tutupan } & \multirow{2}{*}{$\begin{array}{c}\text { Elevasi } \\
\text { Lahan } \\
\text { (mdpl) }\end{array}$} \\
\hline & & $\begin{array}{c}\text { Retensi } \\
\text { (Ha) }\end{array}$ & Lahan & \\
\hline 1 & Kedamaian II & 1,05 & Hutan & $5-6$ \\
\hline 2 & Lebak Sebatok & 3,20 & $\begin{array}{l}\text { Pohon dan } \\
\text { rumput }\end{array}$ & $5-6$ \\
\hline 3 & Pakri & 1,87 & $\begin{array}{l}\text { Pohon dan } \\
\text { rumput }\end{array}$ & $5-6$ \\
\hline 4 & Urip Sumoharjo & 0,97 & $\begin{array}{l}\text { Pohon dan } \\
\text { rumput }\end{array}$ & $4-5$ \\
\hline 5 & Kapten Pursari & 3,98 & $\begin{array}{l}\text { Pohon dan } \\
\text { rumput }\end{array}$ & 5 \\
\hline 6 & Asrama Sekojo & 0,58 & $\begin{array}{c}\text { Rawa semak } \\
\text { belukar }\end{array}$ & 4 \\
\hline 7 & PHDM & 1,54 & $\begin{array}{c}\text { Rawa semak } \\
\text { belukar }\end{array}$ & 4 \\
\hline 8 & Dahri Sembahyu & 1,33 & $\begin{array}{l}\text { Pohon dan } \\
\text { rumput }\end{array}$ & 4 \\
\hline 9 & RE Martadinata & 1,11 & $\begin{array}{l}\text { Pohon dan } \\
\text { rumput }\end{array}$ & 4 \\
\hline 10 & Lorong Amal & 1,43 & $\begin{array}{c}\text { Rawa dan } \\
\text { semak belukar }\end{array}$ & 3 \\
\hline 11 & Ratu Sianum & 0,61 & $\begin{array}{c}\text { Rawa dan } \\
\text { semak belukar }\end{array}$ & 7 \\
\hline 12 & Sabokingking & 2,16 & $\begin{array}{l}\text { Pepohonan dan } \\
\text { rumput }\end{array}$ & 3 \\
\hline
\end{tabular}

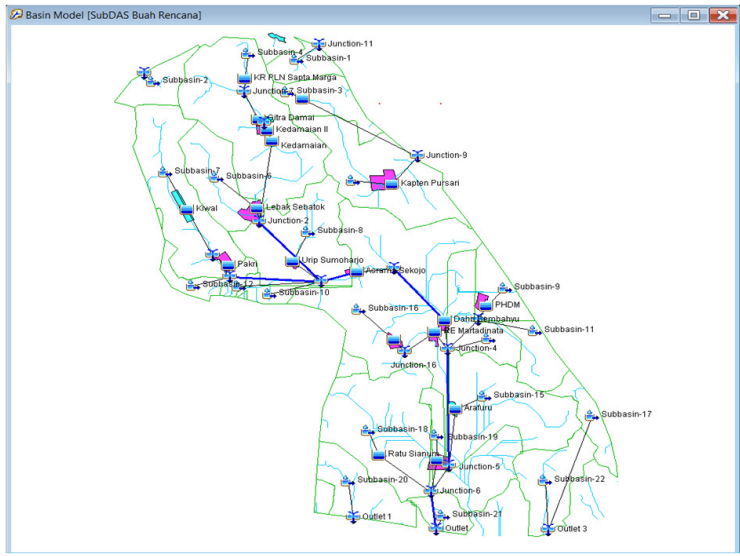

Gambar 15. Basin Model Pemodelan Kolam Retensi Rencana 
Pemodelan kolam retensi rencana pada DAS Buah menghasilkan output berupa debit puncak dari hidrograf inflow dan outflow masing-masing elemen yang dimodelkan, elevasi muka air akibat debit inflow, dan volume tampungan kolam retensi.

\section{Analisis Hasil Simulasi Kolam Retensi Rencana}

1) Analisis Kedalaman Kolam Retensi

Kedalaman kolam retensi efektif didapatkan dari hasil analisis durasi dan tinggi debit puncak inflow hasil pemodelan HEC-HMS. Hasil simulasi HECHMS pada kolam retensi Pakri (Gambar 8) menunjukan debit puncak inflow sebesar 11,26 $\mathrm{m}^{3} /$ det terjadi pada menit ke 70 . Debit puncak ini mengakibatkan naiknya elevasi muka air setinggi 1,71 $\mathrm{m}$ dengan volume tampungan yang dibutuhkan mencapai $32.010 \mathrm{~m}^{3}$. Untuk mengakomodasi kebutuhan volume tampungan dengan luas lahan yang tersedia sebesar 1,871 Ha, maka dibutuhkan kedalaman kolam retensi rencana minimal $3 \mathrm{~m}$. Rekapitulasi analisis kedalaman minimum (untuk semua kolam) dapat dilihat pada Tabel 9.

Tabel 9. Rekapitulasi Hasil Analisis Kolam Retensi Eksisting

\begin{tabular}{|c|c|c|c|c|}
\hline $\begin{array}{l}\text { Nama Kolam } \\
\text { Retensi }\end{array}$ & Koordinat & $\begin{array}{l}\text { Luas } \\
(\mathrm{Ha})\end{array}$ & $\begin{array}{l}\text { Kedalaman } \\
\text { Minimum }\end{array}$ & $\begin{array}{c}\text { Presentase } \\
\text { Reduksi }\end{array}$ \\
\hline Kedamaian II & $\begin{array}{c}104,779^{\circ} \mathrm{LS}- \\
2,945^{\circ} \mathrm{LT}\end{array}$ & 1,051 & $2,5 \mathrm{~m}$ & $58,678 \%$ \\
\hline Lebak Sebatok & $\begin{array}{c}104,776^{\circ} \mathrm{LS}- \\
2,952 \mathrm{LT}\end{array}$ & 3,199 & $3 \mathrm{~m}$ & $61,04 \%$ \\
\hline Pakri & $\begin{array}{c}104,774^{\circ} \mathrm{LS}- \\
2,957^{\circ} \mathrm{LT}\end{array}$ & 1,870 & $3 \mathrm{~m}$ & $20,160 \%$ \\
\hline $\begin{array}{l}\text { Urip } \\
\text { Sumohario }\end{array}$ & $\begin{array}{c}104,779^{\circ} \mathrm{LS}- \\
2,957^{\circ} \mathrm{LT}\end{array}$ & 0,966 & $3 \mathrm{~m}$ & $1,987 \%$ \\
\hline Kapten Pursari & $\begin{array}{c}104,787^{\circ} \mathrm{LS}- \\
2,949^{\circ} \mathrm{LT}\end{array}$ & 3,967 & $3 \mathrm{~m}$ & $45,598 \%$ \\
\hline Asrama Sekojo & $\begin{array}{c}104,784^{\circ} \mathrm{LS}- \\
2,958^{\circ} \mathrm{LT}\end{array}$ & 0,580 & $4 \mathrm{~m}$ & $0,029 \%$ \\
\hline PHDM & $\begin{array}{c}104,795^{\circ} \mathrm{LS}- \\
2,960^{\circ} \mathrm{LT}\end{array}$ & 1,537 & $3 \mathrm{~m}$ & $80,049 \%$ \\
\hline $\begin{array}{l}\text { Dahri } \\
\text { Sembahyu }\end{array}$ & $\begin{array}{c}104,792^{\circ} \mathrm{LS}- \\
2,962^{\circ} \mathrm{LT}\end{array}$ & 1,323 & $4 \mathrm{~m}$ & $2,019 \%$ \\
\hline RE Martadinata & $\begin{array}{c}104,791^{\circ} \mathrm{LS}- \\
2,963^{\circ} \mathrm{LT}\end{array}$ & 1,102 & $3,5 \mathrm{~m}$ & $0,185 \%$ \\
\hline Lorong Amal & $\begin{array}{c}104,787^{\circ} \mathrm{LS}- \\
2,964^{\circ} \mathrm{LT}\end{array}$ & 1,422 & $3,5 \mathrm{~m}$ & $0,276 \%$ \\
\hline Ratu Sianum & $\begin{array}{c}104,787^{\circ} \mathrm{LS}- \\
2,975^{\circ} \mathrm{LT}\end{array}$ & 0,608 & $3,5 \mathrm{~m}$ & $0,482 \%$ \\
\hline Sabokingking & $\begin{array}{c}104,792^{\circ} \mathrm{LS}- \\
2,975^{\circ} \mathrm{LT}\end{array}$ & 2,161 & $3 \mathrm{~m}$ & $64,734 \%$ \\
\hline
\end{tabular}

2) Analisis Reduksi Banjir

Analisis ini menunjukkan penurunan debit banjir puncak akibat kemampuan kolam retensi dalam menampung volume dari debit puncak. Perhitungan presentasi reduksi debit banjir berdasarkan debit inflow dan outflow hasil simulasi HEC-HMS. Dari hasil simulasi kondisi eksisting dan simulasi rencana kolam retensi Pakri (Gambar 16), debit inflow sebesar 11,26 m³/det dapat direduksi menjadi 8,99 $\mathrm{m}^{3} /$ det. Hasil reduksi debit banjir pada kolam retensi Pakri dalam persen sebagai berikut.

$$
\begin{aligned}
\text { Reduksi } Q_{p}(\%) & =\frac{\text { Qp Inflow-Qp Outflow }}{Q p \text { Inflow }} 100 \% \\
& =\frac{11,26-8,99}{11,26} 100 \%=20,160 \%
\end{aligned}
$$

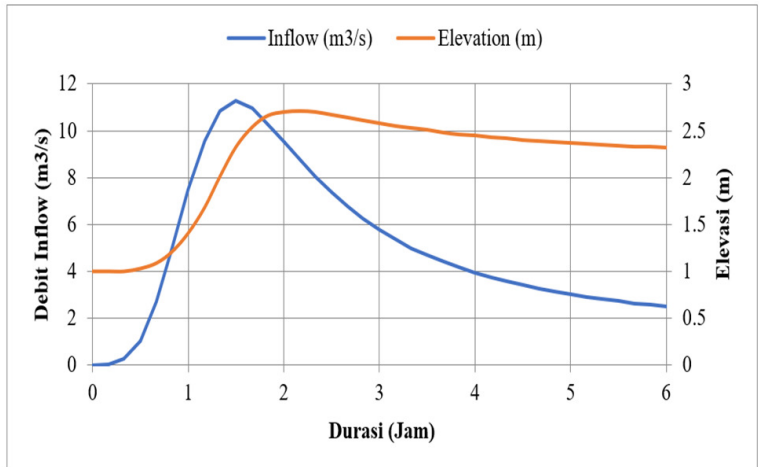

Gambar 16. Grafik Debit dan Elevasi Hasil HEC-HMS Kolam Retensi Pakri

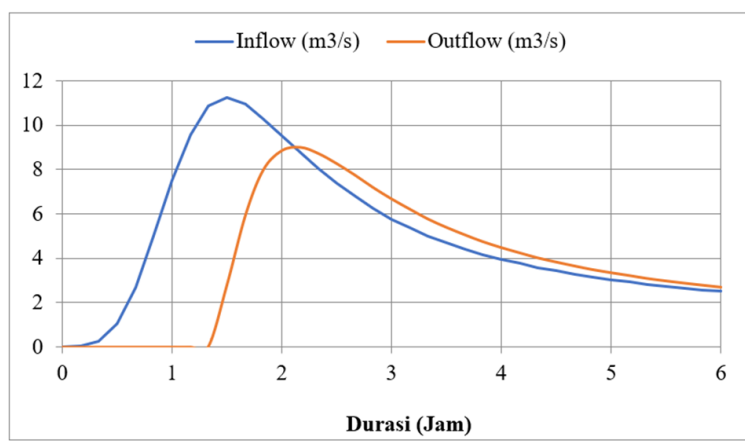

Gambar 17. Hidrograf inflow - outflow Kolam Retensi Pakri

Hasil analisis debit inflow dan outflow kolam retensi Pakri menujukkan bahwa kolam retensi ini dapat mengurangi debit inflow hingga 20,16\%. Rekapitulasi analisis reduksi banjir dapat dilihat pada Tabel 9.

\section{Hasil Analisis Kolam Retensi Rencana}

Berdasarkan hasil analisis kolam retensi rencana dengan pendekatan hidrograf banjir menggunakan HEC-HMS dan analisa spasial dengan Sistem Informasi Geografis, didapatkan persentase reduksi mulai dari $0,185 \%-80,049 \%$ untuk berbagai lokasi kolam retensi rencana. Persentase reduksi ini tergantung pada beberapa variabel antara lain; luas wilayah catchment, ketersediaan lahan untuk kolam retensi dan kedalaman kolam. Luas kolam retensi terbesar yaitu KR Pursari sebesar 3,967 Ha dengan volume tampungan sekitar $120.000 \mathrm{~m}^{3}$. Hal ini memungkinkan karena ketersediaan lahan masih cukup memadai. Sebaliknya, wilayah padat penduduk seperti Sekojo, Jl. R.E Martadinata, lorong Amal, dan Ratu Sianum ketersediaan lahan sangat terbatas sehingga luas kolam retensi rencana hanya berkisar 1-1,4 $\mathrm{Ha}$ dan hal ini tidak berpengaruh signifikan terhadap reduksi debit banjir. 
Cantilever | Volume : 9 | Nomor : 2 | Oktober 2020 | ISSN: 1907-4247 (Print) | ISSN: 2477-4863 (Online)|Website: http://cantilever.id Febrinasti Alia dkk. | Analisis Kapasitas Kolam Retensi untuk Pengendalian Banjir di DAS Buah Kota Palembang

\section{KESIMPULAN}

Berdasarkan hasil analisa yang telah dilakukan, maka dapat ditarik beberapa kesimpulan sebagai berikut:

1) Analisis debit limpasan pada DAS Buah menghasilkan prediksi bahwa subDAS 6 dengan luas daerah tangkapan hujan sebesar 44,752 Ha pada Kelurahan Bukit Sangkal mengalami debit limpasan tertinggi dibandingkan subDAS lainnya yaitu sebesar $15,71 \mathrm{~m}^{3} /$ det. Sedangkan debit limpasan terendah yaitu sebesar $1,27 \mathrm{~m}^{3} / \mathrm{det}$ terdapat di subDAS 10 yang berada di Kelurahan Duku dengan luasan sebesar 10,253 Ha. Sedangakan debit limpasan untuk subDAS lainnya berkisar antara $1,29 \mathrm{~m}^{3} / \mathrm{det}-14,82$ $\mathrm{m}^{3} /$ det.

2) Berdasarkan hasil analisis hidrograf banjir menggunakan HEC-HMS dan analisa spasial dengan Sistem Informasi Geografis didapatkan 12 lokasi kolam retensi rencana yang tersebar di beberapa wilayah rawan banjir DAS Buah. Persentase reduksi debit banjir tergantung pada beberapa variabel antara lain; luas wilayah catchment, ketersediaan lahan untuk kolam retensi dan kedalaman kolam. Masing-masing luasan kolam retensi tersebut dari yang terkecil adalah, Asrama Sekojo (0,58 Ha), Ratu Sianum $(0,61$ Ha), Urip Sumoharjo $(0,966$ Ha $)$, Kedamaian II (1,05 Ha), RE Martadinata (1,11 $\mathrm{Ha})$, Dahri Sembahyu (1,32 Ha), Lorong Amal (1,42 Ha), PHDM (1,54 Ha), Pakri $(1,87 \mathrm{Ha})$, Sabokingking (2,16 Ha), Lebak Sebatok (3,20 Ha), dan Kapten Pursari (3,97 Ha).

3) Berdasarkan analisis kedalaman kolam retensi rencana yang diperoleh dari perbandingan antara debit puncak inflow dan elevasi puncak muka air hasil simulasi HEC-HMS, kedalaman minimum kolam retensi yang dibutuhkan untuk reduksi banjir bervariasi antara $2,5-4 \mathrm{~m}$. Kolam retensi Kedamaian II minimal 2,5 m. Kolam retensi Urip Sumoharjo, PHDM, Pakri, Sabokingking, Lebak Sebatok dan Kapten Pursari membutuhkan kedalaman minimum $3 \mathrm{~m}$. Kolam retensi Lorong
Amal, Ratu Sianum dan RE Martadinata minimal 3,5 $\mathrm{m}$ dan kolam retensi Dahri Sembahyu dan Asrama Sekojo minimal $4 \mathrm{~m}$.

4) Berdasarkan hasil simulasi HEC-HMS, persentase reduksi mulai dari $0,185 \%-80,049 \%$ untuk berbagai lokasi kolam retensi rencana. Persentase reduksi ini tergantung pada beberapa variabel antara lain; luas wilayah catchment, ketersediaan lahan untuk kolam retensi dan kedalaman kolam. Nilai reduksi terbesar terdapat pada kolam retensi PHDM $(80,05 \%)$. Kolam retensi Sabokingking (64,73\%), Lebak Sebatok $(61,04 \%)$, Kedamaian II $(58,68 \%)$, Kapten Pursari (45,60\%), Pakri (20,16\%), Dahri Sembahyu $(2,02 \%)$, Urip Sumoharjo $(1,99 \%)$, Ratu Sianum $(0,48 \%)$, Lorong Amal $(0,28 \%)$, RE Martadinata $(0,19 \%)$ dan Asrama Sekojo $(0,03 \%)$.

\section{REFERENSI}

Al Amin, M. B. (2016). Analisis Genangan Banjir di Kawasan Sekitar Kolam Retensi dan Rencana Pengendaliannya, Studi Kasus: Kolam Retensi Siti Khadijah Palembang. Jurnal Perencanaan Wilayah dan Kota, 27, 69-90.

Alia, F., Al Amin, M. B., \& Kurnia, A. Y. (2019). Evaluasi Aspek Teknis Prasarana Kolam Retensi untuk Pengendalian Banjir di Kecamatan Sukarame, Kalidoni, Kemuning dan Ilir Timur II Palembang. Seminar Nasional AVoER XI, Unsri, Palembang, 23 Oktober 2019.

Alia, F., Rhaptyalyani, \& Ilmiaty, R. S. (2018). Perencanaan Kolam Retensi Untuk Pengendalian Banjir di RSMH Kota Palembang. Cantilever: Jurnal Penelitian dan Kajian Bidang Teknik Sipil, 7(1), 13-20.

Horisky, C., Rahmadi, \& Harahap, T. (2018). Pengaruh Perubahan Pola Pengunaan Lahan Terhadap Banjir di DAS Buah Kota Palembang.Seminar Nasional Hari Air Dunia 2018, Unsri, Palembang, 20 Maret 2018.

Kodoatie, R. J. (2013). Rekayasa dan Manajemen Banjir Kota. Yogyakarta: ANDI Offset.

Suripin. (2004). Sistem Drainase Perkotaan yang Berkelanjutan. Yogyakarta: ANDI Offset.

Triatmodjo, Bambang. (2008). Hidrologi Terapan. Yogyakarta: Beta Offset.

Daftar 20 Kota Rawan Banjir di Indonesia Viva. (2018, November). Diakses dari: https://www.viva.co.id/berita/nasional/1090275-daftar-20kota-rawan-banjir-di-indonesia. 